\title{
Guest Editorial \\ ICTs for Developing Countries - Are There Realistic Answers to the Difficult Problems?
}

\author{
Andrew Wenn \\ Victoria University, Australia
}

\begin{abstract}
Welcome, to this, the first special edition of the Journal for Business Systems, Governance and Ethics. This issue is devoted entirely to the problems of deploying, using and maintaining information and communications technology (ICT) in lesser-developed countries (LDCs). When the call for submissions for this special issue went out in late 2006, this journal was less than 12 months old, although, of course, it had been in the planning stages for longer than this. It is gratifying then to report that readers of this issue will find papers from Australia, Greece, Jordan, and the USA and that the studies contained therein encompass Vietnam, Ecuador and Romania whilst the paper by Imran and Gregor (this issue) presents a multi-country analysis of ICT in lesser developed countries.
\end{abstract}

Likewise, the reviewers, who kindly provided timely and constructive comments, were spread across the globe. If this only seems to underscore the power of ICT to, as Friedman (2005) has written, "flatten" the world, then I urge the reader to read and consider carefully the implications of the papers presented here.

As stated in the call for articles, the idea for this special issue arose out of personal experience. Having just returned from a three month sojourn in Timór-Leste, where I was able to experience at first hand the multitude of complex problems that arise out of the desire and the need to use ICTs within government, the education and corporate sectors I was left wondering if the rhetoric of the digital divide and ICT deployment really matched the practice (Wenn 2007). It was the desire to collect together actual accounts of success and failure that prompted this issue.

A 'digital divide' threatens to exacerbate already-wide gaps between rich and poor, within and among countries. ... Timely access to news and information can promote trade, education, employment, health and wealth. One of the hallmarks of the information society - openness - is a crucial ingredient of democracy and good governance. Information and knowledge are also at the heart of efforts to strengthen tolerance, mutual understanding and respect for diversity. (Annan, 2003 as cited by Livingstone and Helsper 2007, p. 672).

The digital divide (DD) has been discussed and theorised for years, it is seen to exist both within enclaves of developed nations and in the poor nations of this world (Ess and Sudweeks 2001; KaimilaKanjo 1992; Livingstone and Helsper 2007; Sy 2001). Now, whilst Annan (2003 as cited by Livingstone and Helsper 2007, p. 672) stresses the importance, indeed one could conclude the lifeproviding significance of information and knowledge, Afele highlights many issues besides the DD when he says:

What is needed is a poor person's connectivity system that would enable an entire community to utilise a few units of the convergence of television, radio, telephone, Internet, CD-ROM and print media, to offer new prospects in the delivery of sophisticated information to predominantly oral cultures that are currently considered as 'uneconomic' regions of the world. However, this poor person's connectivity system should not imply deployment of the lower end of communications or inefficient tools.

Without appropriate tools, the notion that IT and knowledge flows can lead to sustainable development everywhere may not be realized. (Afele 2003, p. 86 my emphasis) 
It is much more than this as well. "Technological innovation requires a recurrent rather than a one-off investment of money, time and effort on the part of the general public" (Livingstone and Helsper 2007, p. 673) Whilst Livingstone and Helsper are more concerned with internal islands of disadvantage when they say that "there is a risk that increasing internet penetration will exacerbate rather than reduce inequalities" (2007, p. 673) the same thing applies for LDCs whether they are island nations or share a boundary with a better developed neighbour. One only needs to consider the cases of Greece (Markellos, Markellou, Panayiotaki and Stergianeli this issue), Romania (Gudea this issue) or Timór-Leste (T-L) (Wenn 2007). Let us, for instance, consider the case of T-L which whilst I cannot claim that it is typical, at least enables me to raise one or two issues which I haven't seen discussed elsewhere, but are so basic I cannot believe that they haven't raised before.

Timór-Leste is one of the world's newest nations, having gained independence from Indonesia in 2002; before that it was a Portuguese colony from $\sim 1509$ to 1975 . It has a long history of neglect, and like many other colonized nations engaged in a long violent struggle for independence which resulted in 100,000 s of deaths and eventually much destruction (Wheeler 2004). It is one of the world's poorest nations, with an unemployment rate of $30 \%$ in urban areas (much higher elsewhere) (República Democrática de Timór-Leste 2005) and at the time I was there (early 2006) was experiencing increasing levels of civic unrest.

I travelled to T-L as a volunteer working as an IT mentor at one of the privately funded institutes of technology. Everywhere I went within the country there was a demand for IT skills and just as an aside accountants were also in high demand. It is not that, that struck me the most though. The computers that were operating there, were on the whole, cast-offs from wealthy nations, but more importantly riddled with viruses and other debilitating software.

Now, you, the reader, sitting at your desktop or maybe in a comfy armchair reading this on your Internet enabled laptop (this is after all an electronic publication) will probably be thinking so what? Why not install anti-virus software? To which I will say just one thing: 'How do you keep anti-virus software up-to-date without an Internet connection?'

In case you are tempted to ask how the malicious software came to be on the computers in the first place, it should be pointed out that T-L shares a national border with a much more developed Indonesia, and there is a significant movement of people and the software across this border. The generally accepted belief is that viruses are unwittingly brought into T-L through the sharing of computers and USB memory sticks. It is also pertinent to add that an Internet connection was available at the place where I was working but it was dial-up line whose maximum transfer speed was less that $1.4 \mathrm{kbs}-$ obviously a very slow way of downloading a multi-megabyte virus update. Costly also, as telephone calls are charged at a timed-based rate.

There were some Internet Cafés in the capital Dili but the cost of US\$6 per hour for Internet access was far beyond the reach of the average employed citizen who would have been earning less than US $\$ 100$ per month. Just by way of comparison, a hand of bananas cost US\$1 or lunch for six children US\$6. So really Internet access was available for the privileged few (read those volunteers from first world countries).

All of this serves to highlight that "[b]eyond the simple issue of access/no access to ICT come more complex questions of levels of connectivity in terms of capability and distribution of the access concerned. For example, on a practical level, access to a personal computer does not guarantee a connection to the internet." Similarly, "material access to the technology is useless without the requisite skills, knowledge and support to use it effectively." (Selwyn 2004, p. 348 my emphasis) Several decades ago, Carpenter (1989) raised questions about the nature of technology transfer, whilst Wade (2002) questions whether the efforts to bridge the digital divide introduce another form of dependence on the West. (As we see from the T-L example, where the westerners were the only people who could afford to use the Internet). Kaimila-Kanjo (1992) highlights issues of culture and gender. However, there appear to be few studies that look at long-term viability and sustainability of ICT deployments. 
Steyaert (2003) reinforces the idea that access is not everything in his review of Technology and Social Inclusion, Rethinking the Digital Divide (Warschauer 2003) when he comments "The book ceases analysis at access. Despite this concept gaining considerable depth here, there remains a gap between access and social inclusion. ... There is a world of difference between getting someone connected and providing them with enriched educational settings, with full labour market opportunities or enlarged civic engagement." (Steyaert 2003, p. 576) When writing about research into experiences with ICT in rural areas of the Philippines Sy concluded: "[w]iring of public libraries and the civil society, establishment of affordable network access and community telecentres in rural areas, coupled with education and technical training for the digitally disadvantaged Filipinos" are amongst the necessary interventions (Sy 2001, p. 304 my emphasis). This is also mirrored by my experiences in T-L where there are, what can only be described as, great holes in the skills of the Timórese population. A particularly sad state of affairs when we consider that even if the virus-eradication program is successful there would be a shortage of skilled personnel to maintain it.

We see that it is not just a question of what technologies are appropriate for developing nations, but what are the cultural issues involved, what levels of connectivity are needed and are practical and furthermore does the introduction of technology into these countries necessarily ensure knowledge flows? Add to this the need for appropriate training and support, issues of "dominance of certain languages (especially English)" (Looker 2007, p. 711) funding availability and just as importantly questions of the setting of funding priorities, who does it and how (Looker 2007). It is almost enough to make one question, as Looker (2007) does, whether the introduction of ICT is counterproductive.

Leaving that question aside for the time being, one only has to read Gudea's (this issue) contribution to see that grass-roots level demand for ICT will propel its use in some cases just as the cross-fertilisation of ideas combined with trial and error enable a small tourist lodge to install and configure a satellite dish to connect them to the Internet (Karanasios this issue). Rather than co-operative networks as developed in some communities in Romania (Gudea this issue), Fife and Hosman conclude that there is potential for private/public partnerships and outline some of the factors by which such implementations can be regarded as a success (Fife and Hosman this issue).

Steyaert (2003) talks of the potential ICT has to increase civic engagement and a number of the contributions examine issues surrounding the implementation e-government solutions in several countries (Abu-Samaha and Samad this issue; Imran and Gregor this issue; Markellos et al. this issue; Nguyen and Schauder this issue) with Imran and Gregor, in their multi-country study, concluding a multi-level approach that includes efforts by governments, organizations and individuals to provide access "to ICT tools and IT-related education" and furthermore that this should be incremental and sensitive "to local and cultural needs" (Imran and Gregor this issue).

There is no doubt that considerable differences exist between groups of users or potential users but I wanted papers for this issue to extend way beyond discussions of the nature of the DD and I am pleased to say that they do. I hope that everyone who reads the articles that follow finds them as interesting and instructive as I have and that maybe you can find some way of contributing your expertise to make the world a more tolerant, equitable place, one where diversity is treasured and mutual understanding flourishes.

As one of the emphases was on finding solutions to problems, I should perhaps add that after discussion with the T-L people I was working with, we decided to use a free version of an anti-virus program (in this case AVGFree http://free.grisoft.com/ (accessed 19 Sept. 2007)) and implement a system whereby one of the volunteer aid workers who visited an Internet Café regularly would download the update, on a weekly basis and bring it back to the main campus. This would then be copied to a folder on one computer in the main office; those staff members whose computers were networked (four machines in total) could then perform the update over the network (after some training). For the remaining computers, one staff member from each campus or building where computers were installed was made responsible for obtaining the updated files on a visit to the main campus and then to take a walking-tour of each machine on their home campus installing the update. The idea being that the staff would take 
ownership of both the problem and solution. Unfortunately before this could be subjected to more than one round of updates the civil unrest became so dire that the institute temporarily closed its doors. Not long after that, I along with several thousands of others were evacuated from T-L. Once again we see this echoed in the findings of Imran and Gregor.

Finally, I would like to thank all those who contributed articles to this special edition, it was reassuring to see that at least some of the problems of using ICTs in less well off countries can be solved. To the anonymous reviewers who contributed their time and effort and provided constructive feedback to the authors thank you for your efforts, without which this issue would have been much worse off.

\section{References}

Abu-Samaha, A. M. and Samad, Y. A. this issue, 'Challenges to the Jordanian Electronic Government Initiative', Journal of Business Systems Governance and Ethics.

Afele, J. S. C. 2003, Digital Bridges: Developing Countries in the Knowledge Economy, Idea Group, Hershey, PA.

Carpenter, S. R. 1989, 'What Technologies Transfer: The Contingent Nature of Cultural Responses', in Technological Transformations: Contextual and Conceptual Implications, eds Byrne, E. F. and Pitt, J. C., Kluwer, Dordrecht, pp. 163-177.

Ess, C. and Sudweeks, F. 2001, 'On the Edge: Cultural Barriers and Catalysts to IT Diffusion among Remote and Marginalized Communities', New Media and Society, vol. 3, no. 3, pp. 259-269.

Fife, E. and Hosman, L. this issue, 'Public Private Partnerships and the Prospects for Sustainable ICT Projects in the Developing World', Journal of Business Systems Governance and Ethics.

Friedman, T. L. 2005, The World Is Flat: A Brief History of the Globalized World in the Twenty-First Century, Allen Lane, London.

Gudea, S. this issue, 'Internet Access on the Cheap: The Power of the Co-Op', Journal of Business Systems Governance and Ethics.

Imran, A. and Gregor, S. this issue, 'A Comparative Analysis of Strategies for Egovernment in Developing Countries', Journal of Business Systems Governance and Ethics.

Kaimila-Kanjo, G. 1992, Communication, Technology, Gender and Development in Malawi. Masters, Concordia University.

Karanasios, S. this issue, 'Ecuador, the Digital Divide \& Small Tourism Enterprises', Journal of Business Systems Governance and Ethics.

Livingstone, S. and Helsper, E. 2007, 'Gradations in Digital Inclusion: Children, Young People and the Digital Divide', New Media \& Society, vol. 9, no. 4, pp. 671-696.

Looker, E. D. 2007, 'Review of Heather E. Hudson, from Rural Village to Global Village: Telecommunications for Development in the Information Age. London and Mahwah, NJ: Lawrence Erlbaum Associates', New Media \& Society, vol. 9, no. 4, pp. 707-711.

Markellos, K., Markellou, P., Panayiotaki, A. and Stergianeli, E. this issue, 'Current State of Greek eGovernment Initiatives', Journal of Business Systems Governance and Ethics.

Nguyen, T. T. and Schauder, D. this issue, 'Grounding e-Government in Vietnam: Bringing Responsive Government Services to Citizens', Journal of Business Systems Governance and Ethics.

República Democrática de Timór-Leste 2005, Implementation of the Brussels Programme of Action National Mid-Term Review, Dili. Accessed June 2007.

Selwyn, N. 2004, 'Reconsidering Political and Popular Understandings of the 'Digital Divide', New Media \& Society, vol. 6, no. 3, pp. 341-362.

Steyaert, J. 2003, 'Review of Mark Warschauer, Technology and Social Inclusion, Rethinking the Digital Divide', New Media and Society, vol. 4, no. 5, pp. 575-7.

Sy, P. 2001, 'Barangays of IT', New Media and Society, vol. 3, no. 3, pp. 296-312.

Wade, J. H. 2002, 'Bridging the Digital Divide: New Route to Development or New Form of Dependency?' Global Governance, no. 8, pp. 443-466.

Wenn, A. 2007, 'Flat Worlds/Local Crevasses', presented at SPT 2007, 8-11 July 2007, Charleston, SC, USA.

Wheeler, T. 2004, East Timor, Lonely Planet, Footscray. 